\title{
Global Financial Crisis and Stock Market Integration between Northeast Asia and Europe
}

\author{
Geesun Lee ${ }^{1} \&$ Jinho Jeong ${ }^{1}$ \\ ${ }^{1}$ School of Business Administration, Korea University, Republic of Korea \\ Correspondence: Jinho Jeong, School of Business Administration, Korea University, Republic of Korea. Tel: \\ 82-10-2295-5033. E-mail: jayjeong@korea.ac.kr
}

Received: November 20, $2013 \quad$ Accepted: December 28, $2013 \quad$ Online Published: January 16, 2014
doi:10.5539/res.v6n1p61
URL: http://dx.doi.org/10.5539/res.v6n1p61

\begin{abstract}
This study examines the effect of financial crisis on the level of stock market integration. In particular, we investigated the dynamic movements of two regional stock markets, Northeast Asia and Europe during the period between January $1^{\text {st }}, 2000$ and December $31^{\text {st }}$, 2012, with particular attention placed on the global financial crisis (GFC). For this purpose, the paper employs various approaches including DCC-MGARCH, Risk Decomposition, GVAR, and CCOR models to ensure the robustness of empirical findings. The findings of this study are as follows. First, the Northeast Asian stock market remains independent from the European and global stock market movements during the sample period. Second, the European stock market shows an increasing trend of joint integration with Northeast Asian stock market. However, the level of integration is not economically significant. Third, the level of market integration between European and global stock markets had temporally increased during the GFC. However, the level returned to its pre-crisis level in the post-crisis era. The overall empirical evidence suggests that, for either European or global stock market portfolio, constructing a portfolio with Northeast Asian stock market would result in a more efficient portfolio. The results in this paper do not support the view of previous empirical studies which suggested the increased level of integration since the GFC. An increased integration is found to be only unique to the crisis period. In sum, the market integration is a dynamic process, and the financial crisis did not uniformly affect the level of stock market integration.
\end{abstract}

Keywords: market integration, risk decomposition, dynamic conditional correlation, diversification

\section{Introduction}

The advancements in information technology, the rise of multi-national corporations, and the relief of traditional trade barriers have increased the economic linkages across countries and have facilitated the creation of regional economic cooperation. It has been suggested that the capital market integration leads to an efficient financial market by increasing the liquidity and reducing the transaction costs. In addition, an integrated stock market may contribute to the market stabilization because it reduces the market volatility by sharing the macroeconomic shocks. Empirical papers investigating the market integration have been mainly limited to individual stock markets in developed countries. (Note 1)

These studies generally point to a higher level of integration among stock markets after macroeconomic shocks such as the recent global financial crisis (GFC) and the 1997 Asian financial crisis. However, the generalization of empirical results needs a caution because they are based on different methodologies, time periods, and countries.

This paper contributes to the existing literature by investigating the dynamic pattern of integration between aggregated stock markets. In particular, we examine the pattern of integration between two regions, Northeast Asia and Europe, by using various dynamic models to ensure the robustness of empirical findings. The advantage of focusing on aggregated regional market is that the specification of the empirical model can be simplified with regional markets. Given the large number of countries in each region, it is almost impossible to construct a model which simultaneously links among all local markets in the region. According to the modern economic trends, the economic linkages are so strongly tied across regions or the economic blocs rather than across the individual markets. From EU's perspective, the integration of individual capital markets leads to a convergence of European economies, and broadens investment opportunities for both investors and corporations. Recently, however, the benefits of capital market integration in this region have been severely affected by the 
GFC, and the effect is pervasive and tenacious. The European countries are still facing turbulence years and the problem is far from being solved in spite of various efforts made by the ECB's measures. Further actions may be needed to stabilize this regional market, and one of those actions would be the diversification of EU market through increasing its linkages with the growing markets outside the Eurozone such as Northeast Asia which includes China, Japan, and Korea.

China, Japan, and Korea are the EU's second, seventh, and tenth largest trading partners, covering 13.8, 3.6, and 2.1 percent of EU trade, respectively. (Note 2)

Currently, the three countries' combined GDP account for about 20 percent of the world's total and 70 percent of Asia's. These three countries recognized the importance of integrated market and started to negotiate the three nations FTA. (Note 3)

If they reach an agreement, an integrated capital market of those three main Northeast Asian countries would become a powerful economic force with the combined Gross Domestic Product (GDP) of \$15.4 trillion USD, the second biggest economic force following the NAFTA ( $\$ 18.6$ trillion USD) and bigger than the EU ( $\$ 12.1$ trillion USD), and would strongly affect the world economic markets. To our knowledge, an analysis of stock market integration between Northeast Asian and European stock markets still lacks in the literature. This paper feels the gap in this line of research by investigating the dynamic pattern of stock market movements between these two blocs.

The paper uses various methodological frameworks which analyze the dynamics of stock market integration in order to ensure the robustness of the empirical results. We apply Dynamic Conditional Correlation Multivariate Generalized Autoregressive Conditional Heteroskedasticity (DCC-MGARCH), Risk Decomposition, Generalized Variance (GVAR), and Collective Correlation (CCOR) models to reflect a time-varying integration process and to measure an overall level of aggregate market integration. A major advantage of using DCC-MGARCH model is that it allows for explicit time variation in the correlation matrix of market returns. The Risk Decomposition model is employed to consider the time-varying evolution of stock market linkages by computing the global and regional markets' contribution to a particular bloc's stock market. In addition, GVAR and CCOR models are used to signify the overall market volatility and dependency as scalar measures. The GVAR model helps us to easily compare the overall volatility of various markets across different aggregate markets and the CCOR model is useful to measure the linear dependency between aggregate markets.

Finally, we extend the sample data up to the end of year 2012 to avoid reaching the erroneous conclusion based on a relatively short investigation period. The evidence of increased level of market integration after the GFC seemed obvious at least in short-term perspective as documented in the previous studies. However, the argument is not convincing as it stands because the sample data for the post-crisis period were not sufficient enough to fully reflect the effect of crisis on the level of market integration.

\section{Literature Review}

Numerous researches have investigated the stock market integration. Early works in this area analyzed the correlation coefficients across markets and suggested that the integration exists. Longin and Solnik (1995) found that the cross-country stock market correlations in seven major European countries increased over time from 1970 to 1990. Karolyi and Stulz (1996) analyzed the daily stock return co-movements between Japanese and global stock markets from 1988 to 1992 and found evidence that there were significant market co-movements. Johnson and Soenen (2002) studied the equity market integration between Japanese stock market and the other twelve stock markets in Asia and found that those Asian markets were highly integrated with Japanese stock market. They also found that a higher import share as well as a greater differential in inflation rates, real interest rates, and GDP growth rates has negative effects on the stock market co-movements.

However, Forbes and Rigobon (2002) argued that the estimates of cross-market correlations tend to be biased upward especially during a crisis or a turbulence, and that conditional cross-market coefficients do not infer the market interdependence or the contagion. Therefore, they argued that it is not appropriate to distinguish the interdependence, co-movements, or contagion from the correlation relationships when the markets are highly volatile.

Recent papers have analyzed the financial market integration within ARCH or GARCH framework which explicitly deals with the time varying volatility issues. Lucey and Voronkova (2008) investigated the impact of Russian crisis on both short-run and long-run linkages between Russian and other European emerging and developed equity markets within cointegration and DCC-MGARCH frameworks. They found that Russian equity market remained isolated from the influence of international markets in the long run. They also pointed 
out that while a structural break might have occurred in the short run during the Russian crisis, it did not alter the nature of long-run relationships. Lahrech and Sylwester (2011) used DCC-MGARCH and smooth transition models to track how the correlations vary over time across several Latin American stock markets and global stock market. They concluded that co-movements across those stock markets have increased over time, though the magnitude and the speed varied across markets. Dajcman et al. (2012) applied DCC-MGARCH model to examine the co-movement dynamics across the stock markets of U.K., Germany, France, and Austria. They argued that co-movements across market returns are time-varying, and that the GFC did not uniformly increase the degree of co-movements across stock market returns at all scales. Kazi et al. (2013) applied DCC-MGARCH model and investigated the co-movements between global stock market and sixteen OECD countries' stock markets to examine whether there were any shifts in the pattern of contagion effects after the GFC. They found significant evidence of shift-contagion effects arose from the GFC in most of the OECD stock markets, except Japan, Germany, Italy, and the United Kingdom.

Another group of papers used asset pricing models regarding the market integration. Bekaert and Harvey (1995) applied an asset pricing technique and proposed a measure of capital market integration arising from a conditional regime-switching model. They found that a number of emerging markets exhibit time-varying integration. They argued that there were several cases to indicate a decreasing trend of integration between stock markets. De Santis and Gerard $(1997,1998)$ investigated how the expected benefits of international diversification respond to changing market conditions within conditional International Capital Asset Pricing Model (ICAPM) and parsimonious MGARCH process. They found that severe U.S. market declines are contagious at the international market level as the integration of international financial markets increases. Akdogan $(1996,1997)$ developed the risk decomposition model to measure the degree of capital market segmentation. Barari (2004) applied a risk decomposition model to investigate the degree of integration for Latin American stock markets. He found an increasing trend towards the regional market integration relative to the global market integration until the mid-1990s but an increasing trend towards global market integration versus regional market integration during the second half of the 1990s. Bekaert, Harvey, and Ng (2005) proposed a two-factor (global and regional) model to examine the equity market contagion during the period of Mexican and Asian crisis in 1990s. They found no evidence of additional contagion caused by the Mexican crisis. However, they found economically meaningful increases in residual correlation in Asia during the Asian foreign currency crisis. De Jong and De Roon (2005) developed a factor asset pricing model and found that emerging stock markets have become more integrated with global stock markets. Hunter (2006) used a multivariate GARCH-in-Mean asset-pricing model on three Latin American markets: Argentina, Chile and Mexico. He found that these markets have not become integrated into global stock market in the decade after the liberalization.

Finally, several studies investigated the effects of structural changes in the economy on the dynamic linkages of stock returns. Westermann (2004) showed that the introduction of the Euro shifted the linkages across stock markets in the Eurozone. Kim et al. (2005) used an exponential GARCH (EGARCH) model and found that the level of market integration and the market stability increased in the post-Euro era. They argued that observed shifts in the level of market integration after the post-Euro era reflected the overall macroeconomic convergence process associated with the single currency. Celik (2012) used DCC-MGARCH analysis to examine the existence of contagion across foreign exchange markets of several emerging and developed countries during the GFC. They found the evidence of contagion effects for the most of developed and emerging markets and argued that the emerging markets are mostly influenced by the contagion effects during the crisis period. Jones and Olson (2013) used an uncertainty index within the framework of DCC-MGARCH to evaluate the time varying correlations among macroeconomic uncertainty, inflation, and output. They found that the sign of correlation between macroeconomic uncertainty and inflation changed from negative (-) to positive (+) during the late 1990s, whereas the sign of correlation between uncertainty and output was consistently negative (-). Antonakakis et al. (2013) applied DCC-MGARCH model to examine the dynamic correlations of stock market returns, implied volatility, and policy uncertainty, and found that the correlations are time-dependent and sensitive to global recessions.

\section{Methodologies}

In this study, we employ various approaches to analyze the stock market integration. Each model is discussed in the following sections.

\subsection{Risk Decomposition Model}

We followed the basic framework of a risk decomposition model suggested by Akdogan $(1996,1997)$ and Barari (2004) to measure a differential level of market integration across capital markets. For time-varying evolution of 
stock market linkages, the proposed measure is based on computing the contribution of the world and regional benchmark portfolios to a given market's systematic risk. The integration score is calculated as the fraction of systematic risk in total risk. Consider the following single index return-generating model of the $i^{\text {th }}$ region,

$$
\begin{gathered}
R_{i}=a+b_{r} q_{r}+b_{w} R_{w}+\varepsilon_{i} \\
R_{r}=a+b_{r} R_{w}+q_{r}
\end{gathered}
$$

where $R_{i}$ is the rate of return on the $i^{t h}$ region, $R_{r}$ and $R_{w}$ are the rates of return on the benchmark regional and world portfolios, respectively. $q_{r}$ is orthogonal to $R_{w}$ and is obtained as residuals from the equation (2).

The model allows us to effectively break down the rate of return on the $i^{\text {th }}$ region into three components: (1) a component that is perfectly correlated with the rate of return on the other regional market, (2) a component of the world market rate of return that is uncorrelated with the rate of return on that regional market, and (3) a component that is uncorrelated with either the first or the second component. Each component of total variance of $R_{i}$ can be decomposed by dividing each variance terms with $\operatorname{var}\left(R_{i}\right)$. We express the risk arguments as fractions of total risk of investing in the $i^{\text {th }}$ regional portfolio, and the risk components are as follows:

$$
\begin{aligned}
& a_{i}=\frac{b_{i, r}^{2} \operatorname{var}\left(q_{r}\right)}{\operatorname{var}\left(R_{i}\right)} \\
& b_{i}=\frac{b_{i, w}^{2} \operatorname{var}\left(R_{w}\right)}{\operatorname{var}\left(R_{i}\right)} \\
& c_{i}=\frac{\operatorname{var}\left(\varepsilon_{i}\right)}{\operatorname{var}\left(R_{i}\right)}
\end{aligned}
$$

$a_{i}, b_{i}$, and $c_{i}$ represent the regional systematic risk, world systematic risk, and unsystematic risk, respectively. $a_{i}$ represents the regional integration, and $b_{i}$ measures the level of world integration.

\subsection{Dynamic Conditional Correlation}

The DCC model estimates the time-varying stock market correlation coefficients. We used multivariate GARCH framework to capture dynamic correlation patterns and spillover effects. A major advantage of using DCC-MGARCH model is that we can detect the changes in conditional correlations over time when the state of economy changes and that the model accounts for the time-varying volatility behavior of the data series. In addition, we employed GJR model to consider asymmetric market volatility. (Note 4)

The model is specified as follows:

$$
\begin{aligned}
& \text { Conditional Mean }: r_{i, t}=\beta_{i, 0}+\sum_{j=1}^{3} \beta_{i, j} r_{j, t-1}+\varepsilon_{i, t} \\
& \text { Conditional Variance }: \sigma_{i, t}^{2}=\alpha_{i, 0}+\sum_{j=1}^{3} \alpha_{i, j} \varepsilon_{j, t-1}^{2}+\delta_{i} \sigma_{i, t-1}^{2}+\gamma_{i} \varepsilon_{i, t-1}^{2} I \\
& \text { Conditional Covariance }: \sigma_{i j, t}=\rho_{i j, t} \sigma_{i, t} \sigma_{j, t}
\end{aligned}
$$

$$
\begin{aligned}
& r_{i, t}: i^{\text {th }} \text { returnat timet, } \quad i=1 \sim 3(1=\text { Northeast Asia }, 2=E U, 3=\text { Global }) \\
& I=1 \text { if } \varepsilon_{t-1}<0, \text { or } 0 \text { if } \varepsilon_{t-1} \geq 0
\end{aligned}
$$

In equation (3), a significant coefficient indicates that the market $j$ leads the market $i$. In equation (4), the volatility spillovers among markets are estimated by $\alpha_{i, j} . \delta_{i}$ represents the volatility persistency and indicates a tendency of impulse occurred in the past to persist for a period of time. $\gamma_{i}$ represents the degree of asymmetric volatility and implies that the bad news lead to a higher volatility than that caused by the good news. In order to estimate conditional covariance, we used two models: the Constant Conditional Correlation (CCC) and the Dynamic Conditional Correlation (DCC). The CCC model is useful when the model has relatively fewer parameters to estimate than the BEKK (Baba, Engle, Kraft, and Kroner) model. (Note 5)

The model assumes that the conditional correlation is not time-dependent. Engle (2002) suggested the DCC model which considers the time-varying conditional correlations. (Note 6)

\subsection{Generalized Variance and Collective Correlation}

Wilks (1932) defined the Generalized Variance of the population (GVAR) as a determinant of a matrix, $|\boldsymbol{\Sigma}|$, 
and suggested a scalar measure of the overall variance. The model compares the overall volatility of various markets across different aggregate markets. The squared root of GVAR is a Generalized Standard Deviation (GSD). However, it is hard to directly compare the variance because the GVAR tends to be biased upward as the size of portfolio increases. To overcome this problem, Pena and Rodriquez (2003) suggested the Effective Variance (EVAR) and Effective Standard Deviation (ESD).

$$
\begin{gathered}
G V A R=|\boldsymbol{\Sigma}|=\left(\lambda_{1} \lambda_{2} \cdots \lambda_{k}\right), \quad G S D=\sqrt{G V A R} \\
E V A R=|\boldsymbol{\Sigma}|^{1 / k}=\left(\lambda_{1} \lambda_{2} \cdots \lambda_{k}\right)^{1 / k}, \quad E S D=\sqrt{E V A R}
\end{gathered}
$$

As the variance-covariance matrix, $\boldsymbol{\Sigma}$, indicates the variance of overall market, the correlation matrix, $\mathbf{R}$, indicates the linear independency. In contrast, Collective Correlation (CCOR) measures the linear dependency of overall market. However, the difficulty of comparing the matrices with different dimensions still exists. Pena and Rodriquez (2003) suggested the effective correlation (ECOR) to deal with this problem.

$$
\begin{gathered}
|\mathbf{R}|=\frac{|\boldsymbol{\Sigma}|}{\sigma_{1}^{2} \cdots \sigma_{k}^{2}} \\
C C O R=1-|\mathbf{R}|=\left(\lambda_{1} \lambda_{2} \cdots \lambda_{k}\right), \quad E C O R=1-|\mathbf{R}|^{1 / k}=1-\left(\lambda_{1} \lambda_{2} \cdots \lambda_{k}\right)^{1 / k}
\end{gathered}
$$

The overall volatility and dependency of portfolios are expressed by scalar measures. (Note 7)

\section{Data and Sample Statistics}

Table 1 reports the basic descriptive statistics for the data. The global stock market displays the highest mean return with a higher standard deviation than that of the European stock market, and with a lower standard deviation than that of the Northeast Asian stock market. In addition, the mean return for each market is equal to zero, and ANOVA F-statistic indicates that the mean returns are not different across the market. The hypothesis tests for zero mean return indicate that the markets are fairly efficient.

Table 1. Descriptive statistics of daily stock returns (\%), 2000-2012

\begin{tabular}{cccccccc}
\hline Obs:2791 & Mean & Max. & Min. & Std. Dev. & Skewness & Kurtosis & Jarque-Bera \\
\hline N.E. Asia & -0.0199 & 0.0138 & 8.4957 & -10.8616 & 1.2152 & -0.847 & 11.3573 \\
EU & -0.0173 & 0.0226 & 8.0088 & -7.8091 & 1.1205 & -0.2291 & 8.3275 \\
Global & 0.0149 & 0.0394 & 10.4236 & -9.4695 & 1.2945 & -0.1123 & 12.9017 \\
\multicolumn{7}{c}{$t-$ statistics for $H_{0}: \mu=0, N E A(-0.86), E U(-0.81)$, Global $(-0.61)$} \\
ANOVAF-statistics for $H_{0}: \mu_{N E A}=\mu_{E U}=\mu_{\text {Global }}(0.71)$
\end{tabular}

Description: We used the daily close price indices weighted by the yearly average market values of Korea Stock Composite (KOSPI), Shanghai Composite, and Nikkei 225 to construct regional portfolio returns of Northeast Asia. Daily movements of European and global stock markets are measured by Stoxx EU 600 and S\&P500. Sample period covers from January $1^{\text {st }}, 2000$ to December $31^{\text {st }}$, 2012. The data were collected from Yahoo/Finance (finance.yahoo.com) and World Bank (worldbank.org), and the returns were calculated as the continuously compounding rates of returns. Since there is a time lag between the global and Northeast Asian stock markets, we adjusted the date of S\&P500 data by deferring one day (i.e., 2000/01/01 data of S\&P500 is deferred to 2000/01/02). Jarque-Bera test-statistics reject the normality under 1\% significance level.

According to Table 2, showing the unconditional correlations, the European (the global) market is more correlated with Northeast Asian market than with global (the European) market. Figure 1 emphasizes the importance of Northeast Asian stock market by showing the close relationships of Northeast Asian stock market with European and global stock market. In addition, Figure 1 shows a downward pattern of stock market co-movements after the GFC; however, it needs further in-depth analysis to be confirmed. 
Table 2. Correlation matrix for equity market returns

\begin{tabular}{cccc}
\hline $\begin{array}{c}\text { Correlation } \\
\text { (t-statistic) }\end{array}$ & N.E.Asia & EU & Global \\
\hline N.E.Asia & 1 & & \\
EU & $0.3513^{* * *}$ & 1 & \\
& $(-19.82)$ & $0.2578^{* * *}$ & 1 \\
Global & $0.4623^{* * *}$ & $(-14.09)$ & $(-27.53)$ \\
\hline
\end{tabular}

Description: ${ }^{* * *},{ }^{* *}$, and ${ }^{*}$ represent the levels of significance at $1 \%, 5 \%$, and $10 \%$ respectively. For unconditional correlation, the European (the global) market is more correlated with Northeast Asian market than with global (the European) market.

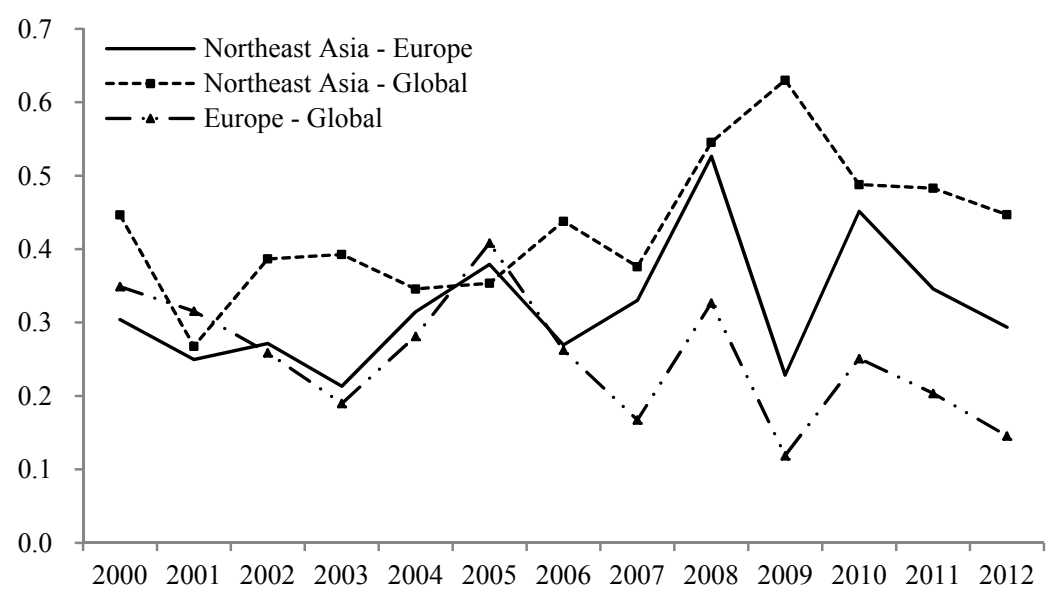

Figure 1. Simple Correlation Coefficient Movements

Description: The unconditional correlation coefficients increased sharply during the GFC while it shows a downward pattern of stock market co-movements, suggesting the decoupling of the market since 2008.

\section{Empirical Results}

\subsection{Risk Decomposition Analysis}

Table 3 provides the estimated historical integration scores for two regional stock markets: Northeast Asia, and Europe. The integration scores indicate that, for the pre-crisis period, regional markets had a low level of integration with the other regional markets with a high degree of unsystematic region-specific risks. During the crisis period, there is no evidence that the level of integration between Northeast Asian stock market and European stock market has increased. However, it is interesting to see that the Northeast Asian stock market showed a segmented trend with global stock market during the crisis period, whereas the European stock market showed an increased level of integration with global stock market. During the post-crisis period, we found an evidence of increased integration between Northeast Asian and European stock markets. Table 3 also indicates that the Northeast Asian stock market remains independent from the global stock market movements during the post-crisis period. On the contrary, the level of integration of European stock market with global stock market dropped sharply in the post-crisis period. Figure 2 shows that the daily movements of Northeast Asian stock market are mainly influenced by the unsystematic risk of the region during the entire sample period. However, the influence of global stock market movements on the European stock market seems to rise during the crisis period. 
Table 3. Integration scores

\begin{tabular}{|c|c|c|c|c|c|c|}
\hline & \multicolumn{3}{|c|}{ Northeast Asia } & \multicolumn{3}{|c|}{ Europe } \\
\hline & $\begin{array}{c}\mathrm{a} \\
(\mathrm{EU})\end{array}$ & $\begin{array}{c}\mathrm{b} \\
\text { (Global) }\end{array}$ & $\begin{array}{c}\mathrm{c} \\
\text { (Region- } \\
\text { specific) }\end{array}$ & $\begin{array}{c}\mathrm{a} \\
(\mathrm{NEA})\end{array}$ & $\begin{array}{c}\mathrm{b} \\
\text { (Global) }\end{array}$ & $\begin{array}{c}\mathrm{c} \\
\text { (Region- } \\
\text { specific) }\end{array}$ \\
\hline 2000 & 0.0435 & 0.0000 & 0.9565 & 0.0395 & 0.0925 & 0.8680 \\
\hline 2001 & 0.0026 & 0.0020 & 0.9954 & 0.0024 & 0.0624 & 0.9352 \\
\hline 2002 & 0.0186 & 0.0017 & 0.9798 & 0.0172 & 0.0736 & 0.9092 \\
\hline 2003 & 0.0078 & 0.0025 & 0.9898 & 0.0074 & 0.0455 & 0.9471 \\
\hline 2004 & 0.0045 & 0.0000 & 0.9954 & 0.0041 & 0.0989 & 0.8970 \\
\hline 2005 & 0.0309 & 0.0090 & 0.9601 & 0.0267 & 0.1439 & 0.8294 \\
\hline 2006 & 0.0086 & 0.0005 & 0.9909 & 0.0080 & 0.0725 & 0.9194 \\
\hline 2007 & 0.0255 & 0.0102 & 0.9643 & 0.0230 & 0.1091 & 0.8679 \\
\hline 2008 & 0.0109 & 0.0120 & 0.9772 & 0.0079 & 0.2770 & 0.7151 \\
\hline 2009 & 0.0001 & 0.0002 & 0.9997 & 0.0001 & 0.0522 & 0.9477 \\
\hline 2010 & 0.0116 & 0.0018 & 0.9866 & 0.0092 & 0.2036 & 0.7872 \\
\hline 2011 & 0.0080 & 0.0052 & 0.9868 & 0.0071 & 0.1196 & 0.8733 \\
\hline 2012 & 0.0107 & 0.0059 & 0.9834 & 0.0098 & 0.0862 & 0.9040 \\
\hline ALL-Period & 0.0005 & 0.0002 & 0.9993 & 0.0004 & 0.1234 & 0.8762 \\
\hline Pre-Crisis & 0.0001 & 0.0001 & 0.9998 & 0.0001 & 0.0763 & 0.9237 \\
\hline During-Crisis & 0.0005 & 0.0001 & 0.9994 & 0.0004 & 0.2316 & 0.7680 \\
\hline Post-Crisis & 0.0107 & 0.0001 & 0.9892 & 0.0095 & 0.1096 & 0.8809 \\
\hline
\end{tabular}

Description: We partitioned the sample period into three sub-periods: pre-crisis, during-crisis, and post-crisis. We consider the outburst of GFC as September $15^{\text {th }}, 2008$ when Lehman Brothers went bankrupt. The overall sample interval is partitioned into three non-overlapping sub periods: (i) pre-crisis period running from January $1^{\text {st }}, 2000$ to September $15^{\text {th }}, 2008$, (ii) during-crisis period extending from September $16^{\text {th }}, 2008$ to December $31^{\text {st }}, 2010$, and (iii) post-crisis period extending from January $1^{\text {st }}, 2011$ to December $31^{\text {st }}, 2012$. The regional events are more likely to be reflected by daily returns of the regional market while global events are likely to be reflected by weekly or monthly returns since global events occurred less frequently than regional events. (Note 8)

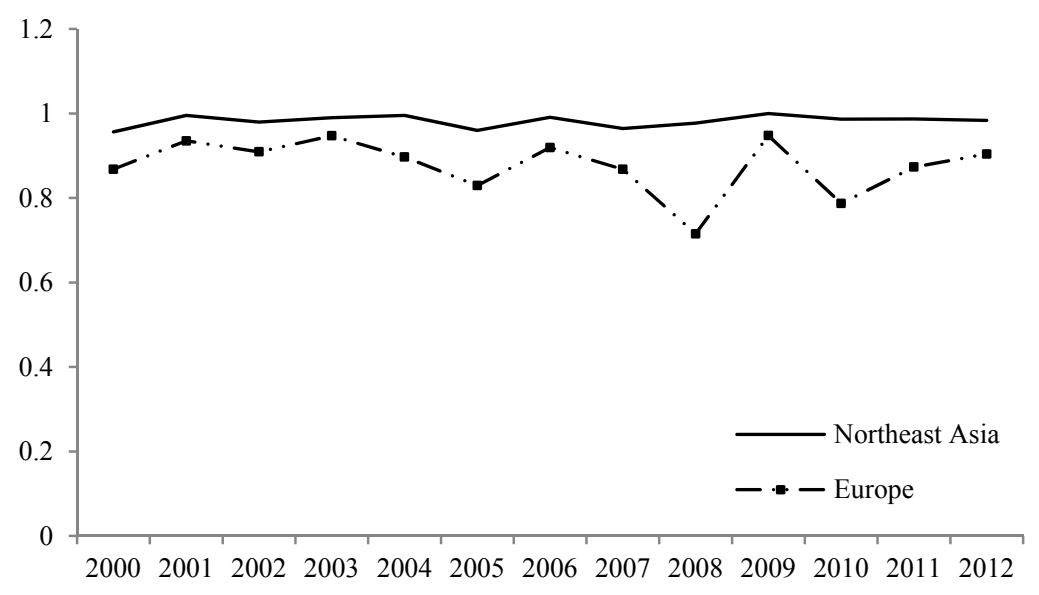

Figure 2. Unsystematic Risks of Northeast Asian and European Markets

Description: The Northeast Asian stock market has higher proportion of unsystematic risk to its total risk than that of the European stock market, indicating that an integrated market of Northeast Asia is relatively independent from the global stock market movements. 


\subsection{Price and Volatility Spillovers}

\subsubsection{All-Period}

Table 4 shows the coefficients of mean and variance equations estimated by a multivariate DCC-VAR-GJR-GARCH model which examines the dynamics of contagion.

Table 4. DCC-VAR-GJR-MGARCH with spillover, all-period

\begin{tabular}{|c|c|c|c|c|c|c|}
\hline \multicolumn{7}{|c|}{ ConditionalMean $: r_{i, t}=\beta_{i, 0}+\sum_{j=1}^{3} \beta_{i, j} r_{j, t-1}+\varepsilon_{i, t}, \quad i, j=1,2,3(N$. E.Asia, EU, Global) } \\
\hline & \multicolumn{2}{|l|}{$\beta_{i, 0}$} & $\beta_{i, 1}$ & $\beta_{i, 2}$ & \multicolumn{2}{|r|}{$\beta_{i, 3}$} \\
\hline $\begin{array}{l}\text { N.E.A } \\
(i=1)\end{array}$ & \multicolumn{2}{|l|}{$\begin{array}{l}0.0023 \\
(0.015)\end{array}$} & $\begin{array}{c}-0.1218^{* * *} \\
(0.019)\end{array}$ & \multicolumn{2}{|l|}{$\begin{array}{c}0.3633^{* * *} \\
(0.018)\end{array}$} & $\begin{array}{c}-0.0597^{* * *} \\
(0.017)\end{array}$ \\
\hline $\begin{array}{c}E U \\
(i=2)\end{array}$ & \multicolumn{2}{|l|}{$\begin{array}{l}0.0069 \\
(0.012)\end{array}$} & $\begin{array}{c}-0.0366^{* *} \\
(0.016)\end{array}$ & \multicolumn{2}{|l|}{$\begin{array}{l}-0.0243 \\
(0.020)\end{array}$} & $\begin{array}{l}0.0062 \\
(0.017)\end{array}$ \\
\hline $\begin{array}{l}\text { Global } \\
(i=3)\end{array}$ & \multicolumn{2}{|l|}{$\begin{array}{c}0.0259^{* *} \\
(0.011) \\
\end{array}$} & $\begin{array}{c}0.0291^{* *} \\
(0.014)\end{array}$ & \multicolumn{2}{|l|}{$\begin{array}{c}0.5108^{* * *} \\
(0.016)\end{array}$} & $\begin{array}{c}-0.1750^{* * *} \\
(0.017)\end{array}$ \\
\hline \multicolumn{7}{|c|}{ ConditionalVariance $: \sigma_{i, t}^{2}=\alpha_{i, 0}+\sum_{j=1}^{3} \alpha_{i, j} \varepsilon_{j, t-1}^{2}+\delta_{i} \sigma_{i, t-1}^{2}+\gamma_{i} \varepsilon_{i, t-1}^{2} I$} \\
\hline & $\alpha_{i, 0}$ & $\alpha_{i, 1}$ & $\alpha_{i, 2}$ & $\alpha_{i, 3}$ & $\delta_{i}$ & $\gamma_{i}$ \\
\hline $\begin{array}{l}N . E . A \\
(i=1)\end{array}$ & $\begin{array}{c}0.0389^{* * *} \\
(0.003)\end{array}$ & $\begin{array}{c}0.0522^{* * *} \\
(0.003)\end{array}$ & $\begin{array}{l}0.0094 \\
(0.007)\end{array}$ & $\begin{array}{l}0.0104 \\
(0.008)\end{array}$ & $\begin{array}{c}0.8856^{* * *} \\
(0.003)\end{array}$ & $\begin{array}{c}0.0476^{* * *} \\
(0.007)\end{array}$ \\
\hline $\begin{array}{c}E U \\
(i=2)\end{array}$ & $\begin{array}{c}0.0120^{* * *} \\
(0.002)\end{array}$ & $\begin{array}{c}-0.0166^{* *} \\
(0.007)\end{array}$ & $\begin{array}{c}0.0127^{* *} \\
(0.006)\end{array}$ & $\begin{array}{l}0.0039 \\
(0.006)\end{array}$ & $\begin{array}{c}0.9330^{* * *} \\
(0.007)\end{array}$ & $\begin{array}{c}0.0935^{* * *} \\
(0.010)\end{array}$ \\
\hline $\begin{array}{l}\text { Global } \\
(i=3)\end{array}$ & $\begin{array}{c}0.0077^{* * *} \\
(0.002) \\
\end{array}$ & $\begin{array}{l}0.0078 \\
(0.006) \\
\end{array}$ & $\begin{array}{c}0.0140^{* * *} \\
(0.005) \\
\end{array}$ & $\begin{array}{c}-0.0062^{* *} \\
(0.003) \\
\end{array}$ & $\begin{array}{c}0.9508^{* * *} \\
(0.006) \\
\end{array}$ & $\begin{array}{c}0.0807^{* * *} \\
(0.007) \\
\end{array}$ \\
\hline
\end{tabular}

$D C C: \mathbf{Q}_{\mathbf{t}}=(1-a-b) \overline{\mathbf{Q}}+a \mathbf{z}_{\mathbf{t}} \mathbf{z}_{\mathrm{t}}^{\prime}+b \mathbf{Q}_{\mathrm{t}-1}$

$a=0.0024^{* *}(0.001), \quad b=0.9972^{* * *}(0.001)$

Description: ${ }^{* * *},{ }^{* *}$, and ${ }^{*}$ represent the levels of significance at $1 \%, 5 \%$, and $10 \%$ respectively. Standard errors are in parentheses. For the entire sample period, the asymmetric volatility measure, $\gamma_{i}$, is significant in all three markets. It implies that the bad news cause a higher volatility than that caused by the good news. The high volatility persistency (from 0.89 to 0.95 ), $\delta_{i}$, indicates that a shock occurred in the past tends to persist. For Northeast Asian stock market, $\beta_{1,2}$, is significantly positive $(0.3633)$ which shows a positive price spillover effect from European stock market. There is a negative price spillover effect $\left(\beta_{1,3}=-0.0597\right)$ from global stock market to the region. For European stock market, there is a negative price spillover effect ( $\left.\beta_{2,1}=-0.0366\right)$ from Northeast Asian stock market. The price spillovers from the global stock market to the European stock market is insignificant ( $\beta_{2,3}=0.0062$ ). For global stock market, positive price spillover effects come from both Northeast Asian $\left(\beta_{3,1}=0.0291\right)$ and European stock markets $\left(\beta_{3,2}=0.5108\right)$. In sum, the European stock market positively affects Northeast Asian and global stock markets in terms of price. The global stock market positively affects the Northeast Asian market. Opposite feedback effects exist between Northeast Asian and European stock markets, and between Northeast Asian and global stock markets. The results suggest that addition of the Northeast Asian stocks to the global and/or European markets can lead to a possibility of constructing a more efficient portfolio. In terms of market volatility, the Northeast Asian stock market is independent from the global stock and European stock market movements. However, the European stock market shows a negative volatility spillover effect $\left(\alpha_{2,1}=-0.0166\right)$ from Northeast Asian stock market and an insignificant volatility spillovers from global stock market. There is a positive volatility spillover effect $\left(\alpha_{3,2}=0.0140\right)$ from European stock market to global stock market. These results again confirm the benefit of adding Northeast Asian stocks to the global and European stocks to enhance the efficiency of the existing portfolio. 


\subsubsection{Pre/Post-Crisis Period}

To investigate the effect of GFC on the level of spillovers, we partitioned the sample period into two subsample periods: (i) pre-crisis period covering from January $1^{\text {st }}, 2000$ to September $15^{\text {th }}, 2008$ and (ii) post-crisis period covering from September $16^{\text {th }}, 2008$ to December $31^{\text {st }}, 2012$. (Note 9)

Table 5. DCC-VAR-GJR-MGARCH with spillover, pre/post-crisis period

\begin{tabular}{|c|c|c|c|c|c|c|c|}
\hline \multicolumn{8}{|c|}{ ConditionalMean $: r_{i, t}=\beta_{i .0}+\sum_{j=1}^{3} \beta_{i, j} r_{j, t-1}+\varepsilon_{i, t}, \quad i, j=1,2,3($ N.E.Asia, EU, Global) } \\
\hline & & \multicolumn{2}{|l|}{$\beta_{i, 0}$} & $\beta_{i, 1}$ & $\beta_{i, 2}$ & \multicolumn{2}{|r|}{$\beta_{i, 3}$} \\
\hline \multirow{2}{*}{$\begin{array}{l}\text { N.E.A } \\
(i=1)\end{array}$} & pre & $\begin{array}{l}-0.0013 \\
(0.020)\end{array}$ & & $\begin{array}{c}-0.0616^{* * *} \\
(0.023)\end{array}$ & $\begin{array}{c}0.3411^{* * *} \\
(0.020)\end{array}$ & \multicolumn{2}{|r|}{$\begin{array}{c}-0.0733^{* * *} \\
(0.022)\end{array}$} \\
\hline & post & $\begin{array}{l}0.0179 \\
(0.027)\end{array}$ & & $\begin{array}{c}-0.2643^{* * *} \\
(0.029)\end{array}$ & $\begin{array}{c}0.4035^{* * *} \\
(0.026)\end{array}$ & \multicolumn{2}{|r|}{$\begin{array}{c}(0.022) \\
-0.0031 \\
(0.024)\end{array}$} \\
\hline \multirow{2}{*}{$\begin{array}{c}E U \\
(i=2)\end{array}$} & pre & $\begin{array}{l}0.0009 \\
(0.015)\end{array}$ & & $\begin{array}{r}-0.0167 \\
(0.017)\end{array}$ & $\begin{array}{c}-0.0556^{* *} \\
(0.022)\end{array}$ & \multicolumn{2}{|r|}{$\begin{array}{c}0.0084 \\
(0.019)\end{array}$} \\
\hline & post & $\begin{array}{l}0.0188 \\
(0.028)\end{array}$ & & $\begin{array}{c}-0.0819^{* * *} \\
(0.030)\end{array}$ & $\begin{array}{l}0.0195 \\
(0.034)\end{array}$ & \multicolumn{2}{|r|}{$\begin{array}{l}0.0104 \\
(0.027)\end{array}$} \\
\hline $\begin{array}{l}\text { Global } \\
(i=3)\end{array}$ & post & $\begin{array}{r}0.0107 \\
(0.015) \\
0.0707^{* *} \\
(0.024) \\
\end{array}$ & & $\begin{array}{c}0.0290^{*} \\
(0.016) \\
0.0062 \\
(0.025) \\
\end{array}$ & $\begin{array}{c}0.6025^{* * *} \\
(0.026) \\
\end{array}$ & \multicolumn{2}{|r|}{$\begin{array}{c}(0.021) \\
-0.1635^{* * *} \\
(0.026)\end{array}$} \\
\hline \multicolumn{8}{|c|}{ ConditionalVariance $: \sigma_{i, t}^{2}=\alpha_{i, 0}+\sum_{j=1}^{3} \alpha_{i, j} \varepsilon_{j, t-1}^{2}+\delta_{i} \sigma_{i, t-1}^{2}+\gamma_{i} \varepsilon_{i, t-1}^{2} I$} \\
\hline & & $\alpha_{i, 0}$ & $\alpha_{i, 1}$ & $\alpha_{i, 2}$ & $\alpha_{i, 3}$ & $\delta_{i}$ & $\gamma_{i}$ \\
\hline N.E.A & pre & $\begin{array}{c}0.0151^{* * *} \\
(0.004)\end{array}$ & $\begin{array}{c}0.0488^{* * *} \\
(0.009)\end{array}$ & $\begin{array}{c}0.0189^{* *} \\
(0.008)\end{array}$ & $\begin{array}{l}-0.0062 \\
(0.007)\end{array}$ & $\begin{array}{c}0.9364^{* * *} \\
(0.008)\end{array}$ & $\begin{array}{l}0.0015 \\
(0.013)\end{array}$ \\
\hline$(i=1)$ & post & $\begin{array}{c}0.0879^{* * *} \\
(0.012)\end{array}$ & $\begin{array}{l}0.0019 \\
(0.023)\end{array}$ & $\begin{array}{l}-0.0132 \\
(0.022)\end{array}$ & $\begin{array}{c}0.0962^{* * *} \\
(0.024)\end{array}$ & $\begin{array}{c}0.8170^{* * * *} \\
(0.018)\end{array}$ & $\begin{array}{c}0.1595^{* * *} \\
(0.025)\end{array}$ \\
\hline$E U$ & pre & $\begin{array}{c}0.0132^{* * * *} \\
(0.001)\end{array}$ & $\begin{array}{c}-0.0262^{* * *} \\
(0.007)\end{array}$ & $\begin{array}{c}-0.0033^{*} \\
(0.002)\end{array}$ & $\begin{array}{l}0.0128^{*} \\
(0.007)\end{array}$ & $\begin{array}{c}0.9354^{* * *} \\
(0.002)\end{array}$ & $\begin{array}{c}0.1097^{* * * *} \\
(0.005)\end{array}$ \\
\hline$(i=2)$ & post & $\begin{array}{c}0.0211^{* * *} \\
(0.005)\end{array}$ & $\begin{array}{c}-0.0188 \\
(0.015)\end{array}$ & $\begin{array}{c}0.0236^{* *} \\
(0.010)\end{array}$ & $\begin{array}{l}0.0191 \\
(0.016)\end{array}$ & $\begin{array}{c}0.9208^{* * * *} \\
(0.008)\end{array}$ & $\begin{array}{c}0.0859^{* * *} \\
(0.021)\end{array}$ \\
\hline Global & pre & $\begin{array}{c}0.0025^{* * *} \\
(0.001)\end{array}$ & $\begin{array}{l}0.0040 \\
(0.004)\end{array}$ & $\begin{array}{l}0.0069 \\
(0.005)\end{array}$ & $\begin{array}{c}-0.0094^{* *} \\
(0.004)\end{array}$ & $\begin{array}{c}0.9733^{* * *} \\
(0.003)\end{array}$ & $\begin{array}{c}0.0625^{* * *} \\
(0.008)\end{array}$ \\
\hline$(i=3)$ & post & $\begin{array}{c}0.0172^{* * *} \\
(0.004)\end{array}$ & $\begin{array}{c}0.0420^{* *} \\
(0.017)\end{array}$ & $\begin{array}{c}0.0442^{* * *} \\
(0.010)\end{array}$ & $\begin{array}{l}-0.0041 \\
(0.018)\end{array}$ & $\begin{array}{c}0.9231^{* * *} \\
(0.013)\end{array}$ & $\begin{array}{c}0.0734^{* * *} \\
(0.018)\end{array}$ \\
\hline
\end{tabular}

Description: ${ }^{* * *},{ }^{* *}$, and ${ }^{*}$ represent the levels of significance at $1 \%, 5 \%$, and $10 \%$ respectively. Standard errors are in parentheses. The price spillover effect from European stock market to Northeast Asian stock market has increased from the pre-crisis period $\beta_{1,2}$ of 0.3411 to the post-crisis period $\beta_{1,2}$ of 0.4035 . The price spillover effect from Northeast Asian stock market to European stock market has increased (in absolute value) from the pre-crisis period $\beta_{2,1}$ of -0.0167 to the post-crisis period $\beta_{2,1}$ of -0.0819 . The results imply that the GFC strengthened the price spillovers between these two regional markets. On the contrary, the price spillover effect from global stock market to Northeast Asian stock market has decreased from the pre-crisis period $\beta_{1,3}$ of -0.0733 to the post-crisis period $\beta_{1,3}$ of -0.0031 . The price spillover effect from Northeast Asian stock market to global stock market has also decreased from the pre-crisis period $\beta_{3,1}$ of 0.0290 to the post-crisis $\beta_{3,1}$ of 0.0062 . The results might be due to the relatively independent movement of Chinese market in Northeast Asia region during the post-crisis period. (Note 10)

The evidence shows that the GFC weakened the price spillovers between European stock market and Northeast Asian stock market. The price spillover effect from European stock market to global stock market has increased from the pre-crisis period $\beta_{3,2}$ of 0.4448 to the post-crisis period $\beta_{3,2}$ of 0.6025 , indicating that the GFC intensified the spillovers between these two markets. The volatility spillover effect from European stock market 
to Northeast Asian stock market has decreased from the pre-crisis period $\alpha_{1,2}$ of 0.0189 to the post-crisis period $\alpha_{1,2}$ of -0.0132 . The volatility spillover effect from Northeast Asian stock market to European stock market has also decreased (in absolute value) from the pre-crisis period $\alpha_{2,1}$ of -0.0262 to the post-crisis period $\alpha_{2,1}$ of -0.0188 . The results suggest that the GFC has decreased the volatility spillovers between these two regional markets. On the contrary, the volatility spillover effect from global stock market to Northeast Asian stock market has increased from the pre-crisis $\alpha_{1,3}$ of -0.0062 to the post-crisis $\alpha_{1,3}$ of 0.0962 . The volatility spillover effect from Northeast Asian market to global stock market has also increased from the pre-crisis $\alpha_{3,1}$ of 0.0040 to the post-crisis $\alpha_{3,1}$ of 0.0420 . The results indicate that the GFC boosted the volatility spillover between these two markets. The volatility spillover effect from global stock market to European stock market has increased from the pre-crisis period $\alpha_{2,3}$ of 0.0128 to the post-crisis period $\alpha_{2,3}$ of 0.0191 . The volatility spillover effect from European stock market to global stock market has increased from the pre-crisis period $\alpha_{3,2}$ of 0.0069 to the post-crisis period $\alpha_{3,2}$ of 0.0442 . These results suggest that the GFC has decreased the volatility spillover from global stock market to European stock market and has increased the effect from European stock market to global stock market.

To sum up, the 2008 GFC severely affected the dynamics of contagion and integration process in stock markets. The patterns of the effect of financial crisis differed from market to market, and the crisis did not uniformly affect the stock market integration. Overall results imply that the Northeast Asian stock market can play a critical role to create a more efficient portfolio by diversifying the risks of European and global stock markets. This implication will be further investigated by the following analysis of DCC model.

\subsubsection{Analysis}

The conditional correlation coefficients estimated from DCC and CCC models are plotted in Figure 3. The CCC coefficients show that the correlation coefficients increased sharply after the GFC except the correlation between European and global stock markets. However, the DCC coefficients strongly suggest that the increased correlations among the stock markets during the financial crisis period have been significantly decreased in the post-crisis era and that the global stock market movements have been shifting towards the market segmentation. Again, the results imply that Northeast Asian stock market is useful to diversify the risks of the existing portfolios of European and global stock markets. 

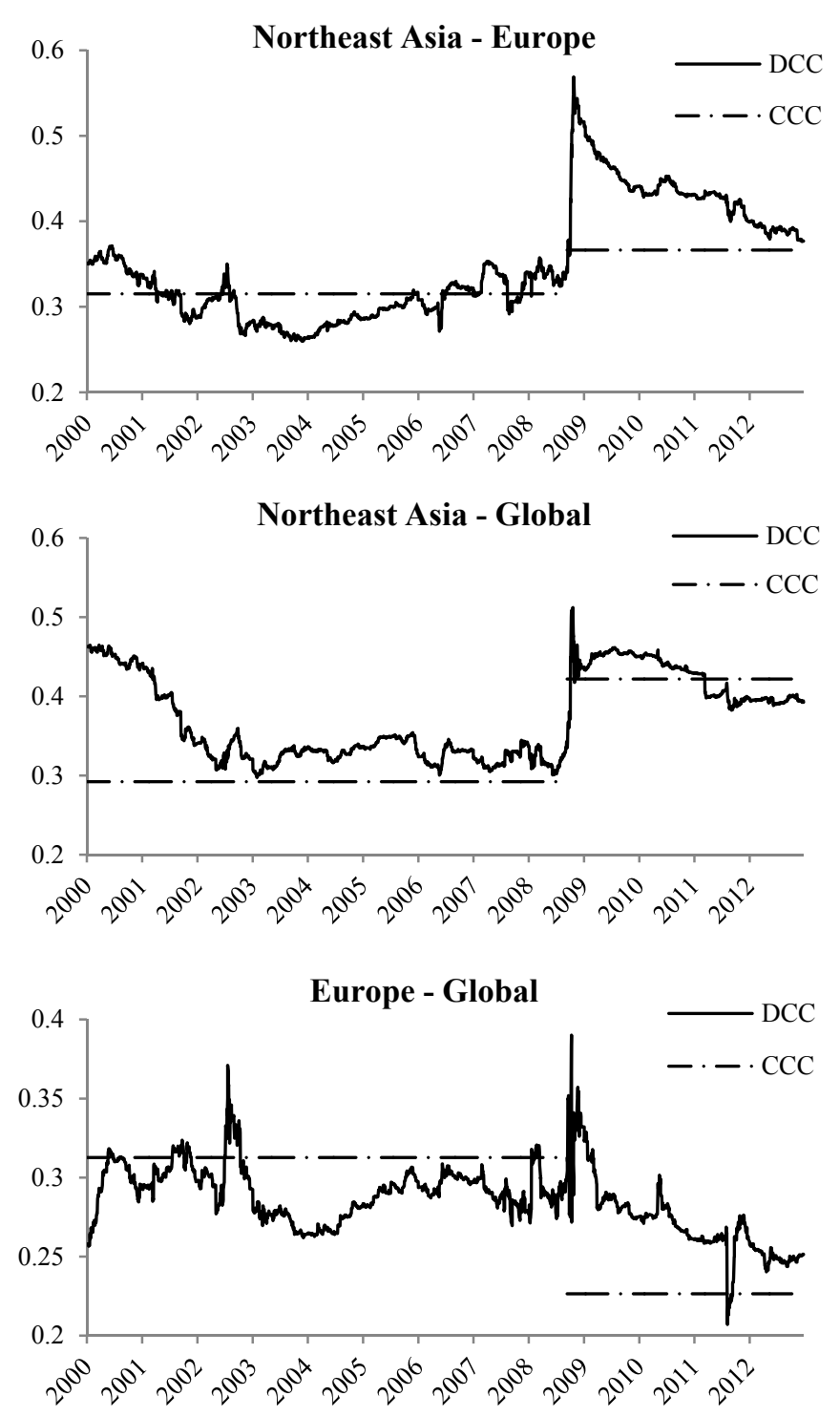

Figure 3. Conditional correlations

Description: The CCC coefficients indicate that the correlation coefficients increased sharply after the GFC, except the case between European and global stock markets. However, the DCC coefficients strongly suggest that the increased correlations among the stock markets during the financial crisis period have been significantly decreased in the post-crisis era.

\subsection{Overall Market Volatility and Correlation}

According to Figure 4, the GSD indicates that the overall volatility increased sharply during the crisis and that the high volatility persisted to some extent. The GSD, however, does not effectively capture the effects of shocks such as the 911 terror in 2001, Enron scandal in 2002, and Chinese asset market bubble in 2006 because the impact of GFC was too big to reflect the other events. To overcome this problem, we measure ESD which corrects the scale bias. 

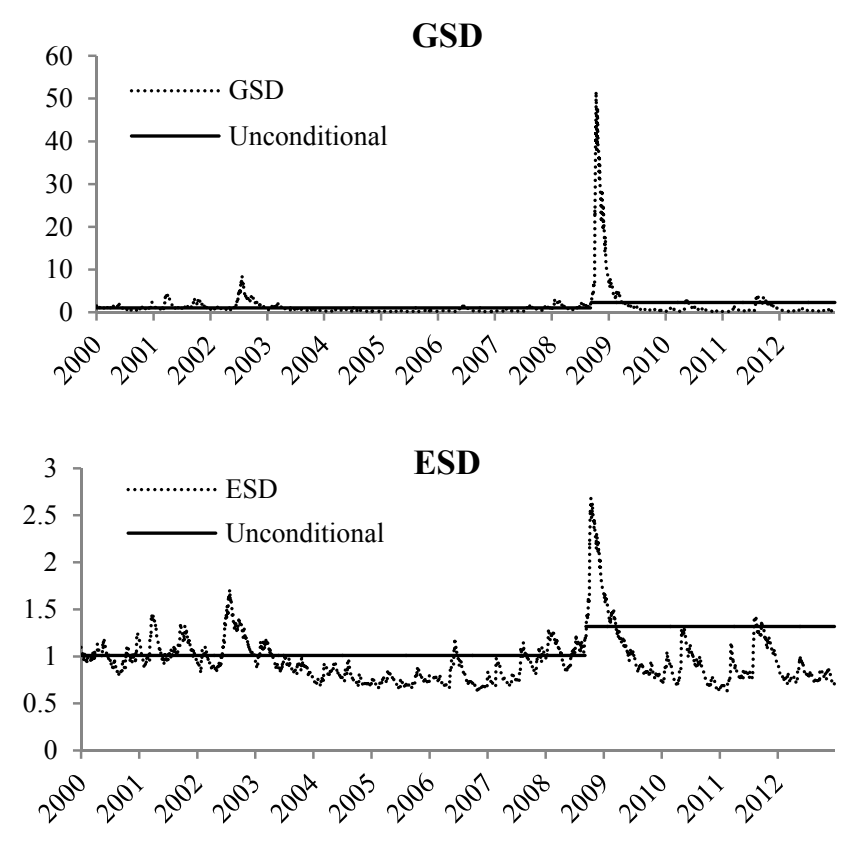

Figure 4. Generalized standard deviation \& effective standard deviation

Description: The ESD effectively captures the impulses in 2001, 2002, 2006, and 2008 incidents and shows that the stock market had a higher volatility than usual when shocks burst.

The results of CCOR and ECOR models are plotted in Figure 5. Unlike the previous studies which presented evidence of accelerated integration after the GFC, the results of this study show that global stock markets shifted the trend towards market segmentation in the post-crisis era and that the higher degree of integration was just temporary phenomena during the crisis period only.
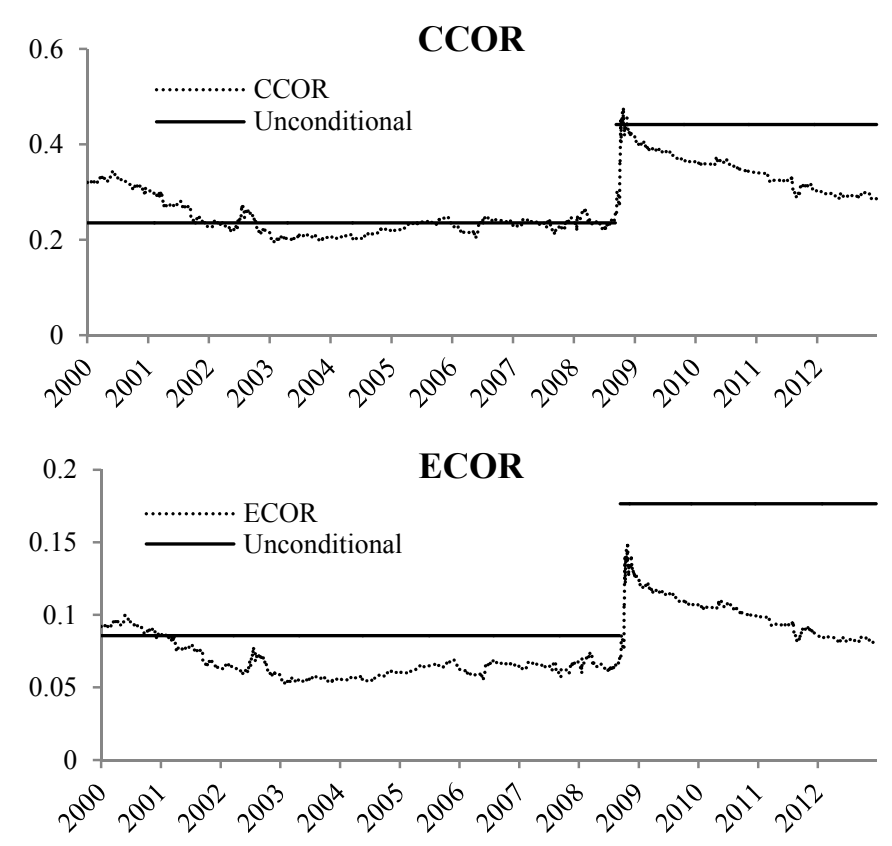

Figure 5. Collective correlation \& effective correlation

Description: The results of these models confirm the results from the DCC analysis. The evidence shows that the overall market correlation was increased during the crisis period and it was decreased steadily during the post-crisis period. 


\section{Summary and Conclusions}

In recognition of the importance of economic linkages in the regional countries, the European countries created the European Union and integrated the capital markets in the region. However, the benefits of capital market integration in the region have been severely affected by the $2008 \mathrm{GFC}$, and the effect is pervasive and tenacious. The problem is far from being solved in spite of various historic measures adopted by European Union to stabilize the market and to stimulate the stagnant economies. This paper explores a possibility of diversification benefit of EU market through its linkages with the Northeast Asian market to secure the stability of European market by investigating the pattern of integration between these two markets.

The three main Northeast Asian countries, China, Japan, and Korea, are in the process of negotiating FTA. It is expected that the three nations FTA would lead to a competent capital market by facilitating more capital and new investment opportunities in the region. However, despite the importance of these two economic blocs, EU and Northeast Asian markets, there have been no empirical studies to investigate the stock market integration process in these two blocs. In this paper, we investigated the dynamic patterns of stock market integration in Northeast Asia and Europe with a special attention focused on the effect of financial crisis on the level of integration. The primary findings of this study are as follows: First, the Northeast Asian stock market remains independent from the European and global stock market movements. Second, the European stock market shows an increasing trend of joint integration with Northeast Asian stock market. However, the level of integration is not economically significant. Third, the level of market integration between European and global stock markets had temporally increased during the GFC. However, the level returned to its pre-crisis level in the post-crisis era.

The overall evidence suggests that, for either European or global stock market portfolio, constructing a portfolio with Northeast Asian stock market would result in a more efficient portfolio and would lead to a significant decline in unsystematic risk. The results in this paper do not support the findings of previous studies which showed the increased level of integration since the GFC. An increased integration is found to be only unique to the crisis period. In sum, the market integration process seems to be dynamic, and the financial crisis did not uniformly affect the pattern of stock market integration. The effect of financial crisis on the market integration is different from market to market.

\section{References}

Akdogan, H. (1996). A suggested approach to country selection in international portfolio diversification. Journal of Portfolio Management, 23(1), 33-39. http://dx.doi.org/10.3905/jpm.1996.409571

Akdogan, H. (1997). Internaitonal security selection under segmentation: Theory and application. Journal of Portfolio Management, 24(1), 82-92. http://dx.doi.org/10.3905/jpm.1997.409625

Antonakakis, N., Chatziantoniou, I., \& Filis, G. (2013). Dynamic co-movements of stock market returns, implied volatility and policy uncertainty. Economics Letters, 120, 87-92. http://dx.doi.org/10.1016/j.econlet.2013.04.004

Barari, M. (2004). Equity market integration in Latin America: A time-varying Integration score analysis. International Review of Financial Analysis, 13, 649-668. http://dx.doi.org/10.1016/j.irfa.2004.02.019

Bekaert, G., \& Harvey, C. (1995). Time varying world market integration. Journal of Finance, 50, 467-509. http://dx.doi.org/10.1111/j.1540-6261.1995.tb04790.x

Bekaert, G., Harvey, C., \& Ng, A. (2005). Market integration and contagion. Journal of Business, 78, 39-69. http://dx.doi.org/10.1086/426519

Bollerslev, T. (1990). Modelling the coherence in short-run nominal exchange rates: a multivariate generalized ARCH model. Review of Economics and Statistics, 72, 498-505. http://dx.doi.org/10.2307/2109358

Celik, S. (2012). The more contagion effect on emerging markets: The evidence of DCC-GARCH model. Economic Modelling, 29, 1946-1959. http://dx.doi.org/10.1016/j.econmod.2012.06.011

Dajcman, S., Festic, M., \& Kavkler, A. (2012). European stock market comovement dynamics during some major financial market turmoils in the period 1997 to 2010: A comparative DCC-GARCH and wavelet $\begin{array}{lllll}\text { correlation analysis. Applied Economics } & \text { Letters, } & 19, & 1249-1256 .\end{array}$ http://dx.doi.org/10.1080/13504851.2011.619481

De Jong, F., \& De Roon, F. (2005). Time-varying market integration and expected returns in emerging markets. Journal of Financial Economics, 78, 583-613. http://dx.doi.org/10.1016/j.jfineco.2004.10.010

De Santis, G., \& Gerard, B. (1997). International asset pricing and portfolio diversification with time-varying 
risk. Journal of Finance, 52, 1881-1912. http://dx.doi.org/10.1111/j.1540-6261.1997.tb02745.x

De Santis, G., \& Gerard, B. (1998). How big is the premium for currency risk. Journal of Financial Economics, 49, 375-412. http://dx.doi.org/10.1016/S0304-405X(98)00029-4

Engle, R. (2002). Dynamic conditional correlation: A simple class of multivariate generalized autoregressive conditional heteroskedasticity models. Journal of Business \& Economic Statistics, 20, 339-350. http://dx.doi.org/10.1198/073500102288618487

Engle, R., \& Kroner, K. (1995). Multivariate simultaneous generalized ARCH. Econometric Theory, 11, 122-150. http://dx.doi.org/10.1017/S0266466600009063

Forbes, K., \& Rigobon, R. (2002). No contagion, only interdependence: Measuring stock market comovements. Journal of Finance, 57, 2223-2261. http://dx.di.org/10.1111/0022-1082.00494

Glosten, L., Jagannathan, R., \& Runkle, D. (1993). On the relation between the expected value and the volatility of the nominal excess return on stocks. Journal of Finance, 48, 1779-1801. http://dx.doi.org/10.1111/j.1540-6261.1993.tb05128.x

Hunter, D. (2006). The evolution of stock market integration in the post-liberalization period-A look at Latin America. Journal of International Money and Finance, 25, 795-826. http://dx.doi.org/10.1016/j.jimonfin.2006.06.001

Johnson, R., \& Soenen, L. (2002). Asian economic integration and stock market co-movement. Journal of Financial Research, 25, 141-157. http://dx.doi.org/10.1111/1475-6803.00009

Johnson, R., \& Soenen, L. (2003). Economic integration and stock market comovement in the Americas. Journal of Multinational Financial Management, 13, 85-100. http://dx.doi.org/10.1016/S1042-444X(02)00035-X

Jones, P., \& Olson, E. (2013). The time-varying correlation between uncertainty, output, and inflation: Evidence $\begin{array}{lllllll}\text { from a } & \text { DCC-GARCH } & \text { model. Economics }\end{array}$ http://dx.doi.org/10.1016/j.econlet.2012.09.012

Karolyi, G., \& Stulz, R. (1996). Why do markets move together? An investigation of U.S.-Japan stock return co-movements. Journal of Finance, 51, 951-986. http://dx.doi.org/10.1111/j.1540-6261.1996.tb02713.x

Kazi, A., Guesmi, K., \& Kaabia, O. (2013). Does shift contagion exist between OECD stock markets during the financial crisis? Journal of Applied Business Research, 29, 469-484.

Kim, S., \& Bera, A. (2007). A scalar measure of volatility and dependence for the financial markets. WorkingPaper.

Kim, S., Moshirian, F., \& Wu, E. (2005). Dynamic stock market integration driven by the European Monetary Union: An empirical analysis. Journal of Banking and Finance, 29, 2475-2502. http://dx.doi.org/10.1016/j.jbankfin.2004.09.002

Lahrech, A., \& Sylwester, K. (2011). U.S. and Latin American stock market linkages. Journal of International Money and Finance, 30, 1341-1357. http://dx.doi.org/10.1016/j.jimonfin.2011.07.004

Longin, E., \& Solnik, B. (1995). Is the correlation in international equity returns constant: 1970-1990. Journal of International Money and Finance, 14, 3-26. http://dx.doi.org/10.1016/0261-5606(94)00001-H

Lucey, B., \& Voronkova, S. (2008). Russian equity market linkages before and after the 1998 crisis: Evidence from stochastic and regime-switching cointegration tests. Journal of International Money and Finance, 27, 1303-1324. http://dx.doi.org/10.1016/j.jimonfin.2008.07.004

Pena, D., \& Rodriquez, J. (2003). Descriptive measures of multivariate scatter and linear dependence. Journal of Multivariate Analysis, 85, 361-374. http://dx.doi.org/10.1016/S0047-259X(02)00061-1

Westermann, F. (2004). Does the Euro affect the dynamic interactions of stock markets in Europe? Evidence from France, Germany and Italy. European Journal of Finance, 10, 139-148. http://dx.doi.org/10.1080/1351847032000143378

Wilks, S. (1932). Certain generalizations in the analysis of variance. Biometrika, 24, 471-494. http://dx.doi.org/10.2307/2331979

\section{Notes}

Note 1. Longin and Solnik (1995), Karolyi and Stulz (1996), De Santis and Gerard (1997, 1998), Lucey and 
Voronkova (2007), Lahrech and Sylwester (2011), Dajcman et al. (2012), and Kazi et al. (2013).

Note 2. IMF and European Commission (2012).

Note 3. China, Japan, and Korea completed the second round of talks for their trilateral trade pact, adding momentum to their push for economic unity in Northeast Asia on August $2^{\text {nd }}, 2013$. The blueprint of the China-Japan-Korea FTA was first suggested in 2003 by the private sector, and the three governments officially declared the start of free trade talks on November, 2012.

Note 4. See Glosten, Jaganathan and Runkle (1993).

Note 5. Engle and Kroner (1995)

Note 6. See Engle (2002) for more detailed discussions and model specifications.

Note 7. See Kim and Bera (2007) for more detailed discussions and reviews.

Note 8 . Hence, the estimated value of the unsystematic risks is high in the case of decomposing the risk of daily returns.

Note 9. The empirical model does not converge if we partition the sample period into three sub-periods: pre-crisis, during-crisis, and post-crisis.

Note 10. We have checked the impulse response function between China and global markets and have found that Chinese market is not sensitive to the global shocks. The results are available upon request.

\section{Copyrights}

Copyright for this article is retained by the author(s), with first publication rights granted to the journal.

This is an open-access article distributed under the terms and conditions of the Creative Commons Attribution license (http://creativecommons.org/licenses/by/3.0/). 